\title{
The Construction of Haier Financial Shared Service Center under the " Integrating Order with Personnel " Model
}

\author{
Anyu Wang \\ School of Accounting, Hangzhou Dianzi University, Hangzhou, China \\ 1067494093@qq.com
}

\begin{abstract}
Founded in Qingdao, Shandong in 1984, Haier Group has grown from a small refrigerator manufacturer to the world's No. 1 white goods brand. In 2005, the concept of " Integrating Order with Personnel " was put forward, and in 2006, under the guidance of this concept, it became one of the first enterprises to establish a financial shared service center in China. This paper mainly analyzes the structure of Haier Financial shared service center from three aspects: the background, development and effect of its construction, so as to deepen the understanding of the financial shared service center.
\end{abstract}

Keywords: Haier; Integrating Order with Personnel; Financial Sharing.

\section{Introduction}

Haier Group is a large multinational company with many subsidiaries scattered around the world, with inconsistent financial accounting standards and redundant financial information. The Haier Group headquarters takes a long time to obtain financial information of subsidiaries, with low efficiency, high cost, and poor timeliness of data acquisition, which has a certain impact on the decision-making of the Haier Group headquarters. To this end, Haier Group began to reform its financial management department in 2006. In May 2007, with the implementation of the globalization strategy, Haier Group began to establish a financial shared service center and adopted the " Integrating Order with Personnel " business-finance integration model. The financial team of Haier Group has established the strategic positioning of "planning for the future, leading a win-win situation", and in accordance with the principle of "more centralized, more decentralized", started the construction of a financial shared service center, which has become a typical example of my country's current financial sharing typical case. Next, this paper introduces the successful road of Haier Group's implementation of business-finance integration under financial sharing from three aspects: the construction background, the construction of the financial shared service center, and the repositioning of construction effects.

\section{Construction Background}

\subsection{Requirements for Financial Personnel}

With the continuous development of the economy, the scale of operation of each enterprise has gradually expanded, and more and more businesses are taking place in the enterprise group. Internal accounting and supervision requirements and standards for financial personnel are also becoming more stringent. For accounting personnel, the enterprise requires them to effectively adjust and monitor the value creation process of the enterprise through the management of comprehensive budgets, final accounts, funds, assets, capital, etc., and become the managers of enterprise value; they are required to participate in and provide resource support for the business development of the enterprise, directly create value for enterprises in financing, tax planning, cost management, etc., and become the management and creator of enterprise value; require them to play strategic decision support by participating in enterprise strategic planning, standard formulation, management innovation, capital operation and risk management role, promote the transformation and upgrading of business structure and cooperation and collaboration, and become a leader in maximizing corporate value. 


\subsection{Requirements for Hardware Facilities}

There is such a demand not only in terms of personnel quality, but also in terms of enterprise hardware. A major change must occur in order to keep up with the pace of development. In this regard, thanks to the rapid update of information transmission and processing technology, emerging financial-related software such as image scanning system, ERP system, bank-enterprise direct connection system, big data mining, etc. came into being, UFIDA, Kingdee, Inspur, Oracle and other system providers continue to innovate and improve their financial products, which greatly improves the convenience and reliability of financial data processing for major enterprises.

Against such a large background, Haier Group maintains the development concept of keeping pace with the times, always takes innovation as the core competitiveness of the enterprise, and conforms to the development trend of the times, becoming one of the earliest enterprises in China to start building a financial shared service center.

\section{Construction of Financial Shared Service Center}

\subsection{The Concept of " Integrating Order with Personnel "}

As early as 2005, Haier put forward the concept of " Integrating Order with Personnel ". Among them, "people" refers to employees, "order" refers to customer value, and "integrating" refers to the integration of employees' value realization and created customer value. The basic meaning of " Integrating Order with Personnel " is that every employee should face customers directly, create customer value, and realize their own value sharing in creating value for users. In this mode, employees are no longer a machine that blindly sticks to their posts, but transformed into a new type of role that is actively innovated and born for users. Different from the traditional model of "users listen to employees, employees listen to enterprises", under the " Integrating Order with Personnel " model, Haier has achieved the goal of "enterprises follow employees, employees follow users", and within the entire group Completed a subversive innovation.

\subsection{Construction of Financial Shared Service Center}

After going through the three stages of famous brand strategy, diversification strategy and internationalization strategy, in 2006, Haier also started the construction of financial shared service center after entering its fourth stage - global brand strategy stage.

\subsubsection{Location of Financial Shared Service Center}

The construction site of the Group Financial shared service center shall be determined comprehensively after analyzing the operating costs, environment, human resources, infrastructure, etc. of the alternative cities. The selected address should meet the development needs of the enterprise and provide a guarantee for the successful construction of the financial shared service center. According to various indicators set by itself, after inspecting several alternative cities such as Beijing, Dalian, Qingdao, Chongqing, Wuhan, Shanghai, etc., Haier finally selected Qingdao as the head office of the financial shared service center for construction., responsible for all domestic business accounting and processing of Haier, and other subsidiaries need to electronically transmit all kinds of bills and other related vouchers to the main center through the image scanning system.

\subsubsection{Shared Center Process Management}

The construction of the financial shared service center not only centralizes the financial department at the organizational level, but also centralizes the accounting personnel at the employee level. At the business level, the connection between various processes is also closer. Based on this, the enterprise must also formulate a strategy that is more in line with the actual situation for the business process, so as to make the business process more efficient. Haier unifies the relevant transaction processing and financial accounting processes after a rigorous analysis of financial organizations, processes, and data. [3] Taking the expense reimbursement process as an example, after the subsidiary's business 
occurs, its employees fill in the reimbursement application online and print the application form, and then the application form is handed over to the person in charge of approval for approval and signature, and the person in charge of approval fills in the reimbursement application online and prints the application one. Then, the application form and the original voucher are scanned by the image scanning system, and the electronic form is generated and transmitted to the financial shared expense center, and the expense center reviews and reimburses the business. After the approval, the relevant documents of the business will be archived and retained, and the expense center will submit the business to the Payable Center, and the Payable Center will make the payment and finally realize the reimbursement. Such a complete set of processing procedures is very smoothly connected, making use of the high speed and speed of information network transmission to a great extent, improving the business processing efficiency of employees, and reflecting the characteristics of information integration in the Haier Financial shared service center.

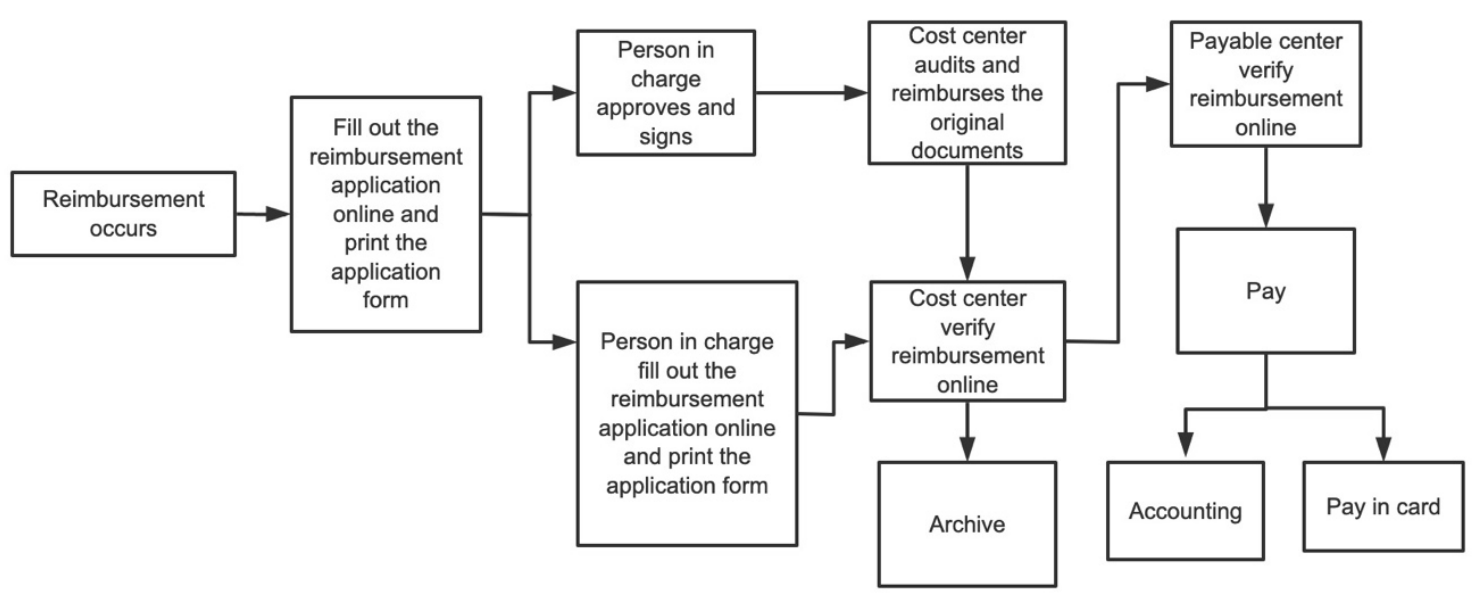

Figure 1. Haier Financial Shared Service Center Expense Reimbursement Process

\subsubsection{Shared Center Hardware Facilities}

In order to provide a strong guarantee for complicated and tedious business processing, Haier has also made great efforts in the introduction of system hardware. ERP system, document image scanning and transmission system, workflow technology, database, data analysis, reporting tool, selfservice reimbursement, electronic payment, electronic billing system, etc., these parts have not yet reached the widespread popularity of technology, but Haier is in It was applied to group business processing in 2006, which not only reflected Haier's determination to develop, but also greatly increased the online work capacity limit of the financial shared service center.

\subsubsection{Organizational Structure}

Haier's entire financial sharing platform is mainly divided into two parts: the accounting platform and the capital platform. In terms of the accounting platform, it is subdivided into 8 modules such as quality management, expense audit, asset accounting, transaction settlement, general ledger report, tax service, collection and payment service, and tax declaration. The quality management module is an important feature that distinguishes Haier Financial Shared Service Center from traditional financial centers. Since the establishment of Haier, the concept of "high quality, high quality" has taken root in the hearts of every Haier employee, and Haier's development has always followed the adherence to quality. Under the guidance of this concept, the characteristic quality management module came into being. Risk management and control, compliance audit, process penetration, performance monitoring and global GAAP, such management and control strengthen Haier's internal supervision and control, and also ensure the stability of Haier's operations to a large extent. From this point of view, there is a more distinctive Haier-style functional module design, and the appearance of the quality management model we have seen. 
Table 1. Organizational Design of Haier Financial Shared Service Center

\begin{tabular}{|c|c|}
\hline \multicolumn{2}{|r|}{ Accounting Platform } \\
\hline Quality Management & risk control, compliance audit, performance monitoring, global GAAP \\
\hline Expense Audit & $\begin{array}{l}\text { integrity management, cost review, execution evaluation, online consultation, } \\
\text { system optimization }\end{array}$ \\
\hline Asset Accounting & procurement verification, asset management, tax receipt authentication \\
\hline Transaction Settlement & bank reconciliation, transaction settlement, risk tracking \\
\hline General Ledger Report & $\begin{array}{l}\text { account monthly closing, external audit coordination, compliance reports, } \\
\text { analysis and early warning }\end{array}$ \\
\hline Tax Service & $\begin{array}{l}\text { tax receipt management, policy redemption, revenue confirmation, simultaneous } \\
\text { account entry }\end{array}$ \\
\hline $\begin{array}{l}\text { Collection and Payment } \\
\text { Service }\end{array}$ & fund collection, fund receipt and payment, gap warning, unified clearing \\
\hline Tax Declaration & tax management, tax declaration, tax relationship, audit coordination \\
\hline \multicolumn{2}{|r|}{ Capital Platform } \\
\hline Financial Risk & $\begin{array}{c}\text { market analysis, rolling forecast, model analysis, policy analysis, exposure } \\
\text { forecast, risk control }\end{array}$ \\
\hline Fund Operation & $\begin{array}{l}\text { forecast system, capital plan, capital monitoring, cash flow forecast, operation } \\
\text { evaluation }\end{array}$ \\
\hline Financing Platform & $\begin{array}{c}\text { credit management, financing planning, channel review, reasonable liabilities, } \\
\text { account management, bank-enterprise relationship }\end{array}$ \\
\hline
\end{tabular}

\subsubsection{Process Construction}

Financial shared services need to optimize business processes while realizing the centralization of financial accounting. The Haier Financial Shared Service Center has carried out an "end-to-end" optimization design for the financial process, sorted it into 6 modules of general ledger, receivables, payables, non-current assets, expense budget control and capital management and established standard business processes.

Haier's financial shared service realizes an end-to-end closed loop through process reengineering, fully integrates logistics, capital flow and information flow, and centralizes accounting services scattered in various business locations to the center for unified processing, so that finance and business are highly coordinated and greatly improved. Improve the quality and efficiency of financial management, effectively control the group's financial risks, and reduce financial costs.

\subsection{The Organic Combination of the Sharing Center and "Integrating Order with Personnel"}

Compared with the traditional financial shared service center, Haier's financial shared service center has its own characteristics in terms of target positioning, functional design, platform construction and bottom-level thinking. Under the guidance of the concept of " Integrating Order with Personnel", Haier pursues the realization of customer value and the innovative development of employees, rather than simply reducing processing costs and improving processing efficiency. This is also an important manifestation of the strategic support undertaken by the Haier Financial shared service center. Not only that, in order to better realize the value of "Order" in "Integrating Order with Personnel", Haier made full use of Internet resources and built a "cloud" platform with scalable service scope through the standardization of processes and the integration of information to help achieve Click "Cloud Orders", "Cloud Documents" and "Cloud Contacts" under "Haier Cloud". In terms of bottom-level thinking, Haier adheres to the spirit of "people" as the main body, gives employees greater authority, emphasizes employees' autonomous control, stimulates employees' subjective initiative, and enables employees to break through the restrictions of positions. To give full play to its own advantages and complete the realization of self-worth. Compared with being passively forced to do high-intensity work, in this mode, employees are more active in rushing and accepting orders, and their work enthusiasm is improved, and their efficiency is naturally greatly improved. 


\section{Construction Effect}

\subsection{Establish a Higher Organizational Structure}

Haier Group has reorganized a new structure and divided the work platform into an accounting platform and a capital platform. The accounting platform is mainly responsible for accounting-related business. It consists of eight modules, each with its own division of labor, which can effectively improve the efficiency of the enterprise. The capital platform is mainly related to capital, and consists of three modules, including financial risk, capital operation and financing. Among them, the quality center is the difference between Haier Group and other groups, and it is also the characteristic of Haier Group. The quality model runs through all links to ensure product quality and business quality, and undertake strategic support tasks.

\subsection{Establish Standardized Business Processes}

The new standardized business process runs through all the businesses of Haier Group. Compared with the original process, the new process breaks the traditional static finance. The integration of finance and information enables enterprises to realize information sharing in a real sense, and solves the problems of incomplete information and omissions in inter-departmental docking and cooperation. Blur the boundaries between departments, making inter-departmental cooperation more smooth, and management decision-making more efficient. The changes in the process allow each worker to increase the efficiency of their work. Standardized processes can also speed up responsiveness to rapidly changing markets.

\subsection{Unified Financial Information System Platform}

Haier Group's financial sharing information platform is based on ERP system GVS, which integrates financial sharing platform, budget management system, internal control system, management accounting report information system, performance evaluation system and imaging system. These can be mainly divided into two parts, accounting information system and management information system. The use of financial information systems can improve work efficiency, accurately capture the reasons for the inefficiency of enterprises, and allow financial information to be communicated quickly and effectively. The existence of financial information systems makes it possible to rebuild financial processes and organizational structures. The financial shared service center enables Haier Group to realize the development of management accounting type, freeing more financial personnel from the accounting business to provide valuable services to enterprises.

\subsection{Delicate Management of Financial Personnel}

Haier Group has carried out refined management of financial personnel under the integration of industry and finance, and divided financial personnel into three categories: business finance, shared finance, and professional finance. As the front-end of business finance, it is necessary to go deep into the business department, first assist the business team to understand user needs and total market volume, use budget variance analysis to display the variance, and provide a reference plan for postevent analysis. Shared finance is used as the back-end, centralized transaction processing, risk management and control, efficient transfer of financial information, and improved resource allocation efficiency. Professional Finance Establish professional financial models and provide professional solutions for different businesses. Haier adopts the " Integrating Order with Personnel " model, which integrates everyone with business orders. Each " Integrating Order with Personnel " is an interest body, a profit center, and each financial officer is his own CEO. Encouragement Employees create value for the enterprise. Haier broke the bureaucratic organizational structure and built an organizational structure with small and micro teams as the basic profit center. In addition, the financial sharing platform under the background of the information network has realized zerodistance information exchange, the speed of data transmission is accelerated, and stakeholders can Timely and efficient information exchange. 


\section{Conclusion}

Haier's financial sharing is not only a form of organization, but also a high-efficiency management model that can achieve efficient transmission of financial information, strengthen corporate management and control capabilities, reduce corporate operational and financial risks, improve resource utilization, and optimize resource allocation.

While pursuing cost reduction, the construction of a new generation of financial sharing should be aimed at improving efficiency, improving customer satisfaction, and promoting service quality. Although Haier has made great achievements in this regard, many Chinese enterprises even if have started or completed their own financial shared service center, still cannot figure out the value of the financial sharing service center to themselves. It is completely wrong to think that the introduction of a system is equivalent to the completion of the financial shared service center. . It only pursues cost reduction and efficiency improvement, and does not combine the organizational framework with reality at all. There is hardware support without personnel changes. Once the construction of such a financial shared service center is carried out, it will definitely be a result of making ends meet. As an effective management tool for the future development of enterprises, the financial shared service model is increasingly favored by many. At the same time, the expansion of services to various types such as decision support and professional services has also become an inevitable development direction. In this regard, Chinese enterprises should continue to learn from the concepts and operation modes of foreign advanced shared services, keep pace with the times, and absorb the essence. The construction of the financial shared service center is a long-term process, and it is also a process of improving the management accounting system. Through the further extension of the business, it provides better services for the financial management reform of the group. Therefore, a successful financial shared service center can be built only by combining the concept with the reality, and Chinese enterprises still have a long way to go in this regard.

\section{References}

[1] Li Hongmei. Research on the Transformation and Development of Finance and Accounting in the Era of "Big Wisdom and Cloud"--Taking ZTE and Haier as Examples [J/OL]. Journal of Anhui Vocational and Technical College of Commerce (Social Science Edition): 1.

[2] Hu Gege, Yang Hanming, Zhou Li. Haier Group's Financial Sharing Road [J]. Finance and Accounting (Financial Management Edition), 2013(09):13.

[3] Wang Zhao, Huang $\mathrm{Xu}, \mathrm{Wu}$ Nianzhi. The way to build a financial shared service model under the background of big data [J]. China Management Information, 2016, 19(01): 27-30.

[4] Li Jing. Research on Haier Group's Financial Sharing Innovation under the "Rendanheyi" Model [D]. Hubei Institute of Economics, 2019: 42.

[5] Guo Yanying. Research on Qingdao Haier Financial Sharing Model Based on Cost-Efficiency [D]. Jilin University of Finance and Economics, 2017: 19.

[6] Li Xuejiao. Research on the Construction of Financial Shared Service Center System [J], Accounting Research, 2017(02):61-62.

[7] Liu Kechen, Tian Ning. The application and discussion of financial sharing services in Haier Group [J]. Modern Marketing (late issue), 2021(04):150-151.

[8] Gu Quangen. Research on strategic policy planning of financial sharing construction of group companies [J]. Friends of Accounting, 2019(21):3.

[9] Cheng Chang. Research on the Innovation of Financial Shared Services for Enterprise Groups -- Based on the Management Practice of Haier Group [J]. Friends of Accounting, 2019(03):90-94. 